\title{
The Level of Student Literacy Towards The Sharia Cooperatives
}

\author{
Ropi Marlina \& Juliana \\ STIE Dr. Khez Muttaqien, Universitas Pendidikan Indonesia \\ E-mail: ropi.maarlina@stiemuttaqien.ac.id, julian@upi.edu
}

\begin{abstract}
This article is motivated by the wrong perception of the understanding and knowledge of Islamic cooperatives. The purpose of this study is to find out the level of student literacy in Islamic cooperatives. The method used is quantitative descriptive method. The number of research samples amounted to 70 active students of the Indonesian Education University representing each faculty. The results showed that students did not fully understand the development agreement used in Islamic cooperatives that is included in thecontract syirkah. However, in general students' literacy toward usury and the compatibility of Islamic cooperatives with Islamic principles is largely understood. The implication of this research shows that there is a need to increase literacy to students as younger generation more specifically about the existing contractual agreements in Islamic cooperatives.
\end{abstract}

Keywords. Sharia Banking, Sharia Cooperative, Syirkah, Student Literacy

\section{INTRODUCTION}

Cooperatives are formal microfinance institutions engaged in non-financial fields. The existence of cooperatives is needed in various groups from small to medium-sized communities because it is easily accessible. Cooperatives are also a form of business entity that continues to grow, both in terms of the amount, volume set and the Remaining Operations (SHU) distributed to its members (Ayadi, 2010).

Based on data from the Ministry of Cooperatives and MSMEs as of December 31, 2019 cooperatives active in Indonesia numbered 123,048 units, from before the reform of the total cooperative in 2014 amounted to 212,570 units. In 2017 the Ministry of Cooperatives and SMEs has dissolved 40,013 cooperative units. This is because, the low activity of cooperative members in managing and educating the community, the lack of capital to develop cooperative businesses, and the low contribution of cooperatives to the National GDP which only reaches around $4.48 \%$. In Indonesia, conventional cooperatives occupy the largest number compared to Islamic cooperatives. In conventional cooperatives still give interest to each customer as a cooperative advantage, and the low level of honesty from cooperative managers because of collusion between managers that causes loss of public trust as customers. This is because conventional cooperatives still use contracts that tend to conflict with Islamic principles such as usury, etc. Therefore, the establishment of Islamic cooperatives is a practical answer to the problems that occur (Shafii, 2017).

Sharia cooperatives are microfinance institutions that raise funds from members and channel them to members for the welfare of the members of the cooperative and surrounding communities (Kartasapoetra; 2013). According to BPS data the number of Muslims in Indonesia has reached around $85 \%$, which is 228,608 . 665. The data shows that the majority of Indonesian citizens are Muslim, so that it can be a potential for the growth of Islamic cooperatives in Indonesia. However, the lack of public knowledge about Islamic cooperatives is one of the obstacles to the growth of Islamic cooperatives in Indonesia. As stated by the OJK, it is stated that public literacy in the Islamic financial services industry is still very low at only $8.1 \%$, while conventional is $29.5 \%$ (OJK, 2017).

Financial Economics Literacy among students based on Chen and Volpe's research in 1998 in California and several other countries with 924 student respondents showed that the level of financial 
literacy was in the low category. The results showed that 53\% of students answered the questions correctly. (Nuryana; 2019).

Indonesian University of Education as one of the educational institutions whose students come from all over Indonesia is expected to be a rule model for the development of sharia products because UPI has a scientific, educative and religious motto. It is hoped that with this religious motto student understanding is comparable to the understanding of Islamic cooperatives.

The results of research by Marlina and Pratama (2017) state that Sharia Cooperatives as a Solution for Applying the Legal Syirkah Agreement is that in implementing syirkah in accordance with Islamic principles, conventional cooperatives must be converted to sharia cooperatives so that Muslims can carry out muamalah activities according to the rules sharia.

Juliana et al (2019) research on BMT (Sharia Cooperative) shows the level of perception of sharia compliance with murabaha products in BMT is in good category, although there are some indicators that are lacking, such as murabaha goods not belonging to BMT and the traded object does not exist when signing a contract .

Based on the above phenomenon, the authors conducted research on student literacy on sharia cooperatives, syirkah contracts in sharia cooperatives, ulama views, and implementation of syirkah contracts in sharia cooperatives.

The purpose of this study is to elaborate the concept of Islamic cooperatives and to find out more about the views of scholars regarding Islamic cooperatives. As well as knowing the level of literacy of UPI students towards Sharia Cooperatives.

\section{LITERATURE REVIEW}

\section{Sharia Cooperatives}

In the language, the word cooperative is derived from the English word operation which means joint effort (Revrisond Baswir, 2000). Whereas in Arabic, the Cooperative is called syirkah which means al- Ikhtilath, which is a union / partnership (Zaidi; 2003). According to Law Number 25 of 1992 Article 1 Paragraph 1 concerning cooperatives states that cooperatives are "business entities consisting of individuals or cooperative legal entities by basing their activities based on cooperative principles and at the same time as a people's economic movement based on the principle of kinship". This understanding is almost the same as sharia cooperatives, namely cooperative business entities whose activities are engaged in financing, investment, and savings by using sharia principles, namely profit sharing patterns or often referred to as sharia financial services cooperatives.

Sharia cooperatives are a type of joint business consisting of individuals or a legal entity, with a family system which in its implementation is based on sharia principles. According to Permen K.UMKM no. 35.3Per / M.KUMKM / X / 2007, "Sharia cooperatives are defined as Sharia Financial Services Cooperatives, namely cooperatives whose business activities are engaged in financing, investment and savings in accordance with sharia patterns."

\section{Literacy}

Suparman Zen Kmu (2016) in his journal entitled Indonesian Capital Market Literacy states that literacy is an ability both in reading and writing. While Irwin et al. (1993) explains Literacy is one's ability to use written or printed information to develop knowledge so that it benefits society.

Financial literacy is the knowledge(knowledge),confidence(confidence) and skills(skills), which affects the attitude(attitude)and behavior(behavior)to improve the quality of decision-making and financial management in order to achieve prosperity (FSA; 2017). While literacy Islamic finance can be interpreted as Islamic financial literacy. (Nuryana; 2019).

\section{RESEARCH METHODOLOGY}

The method used is descriptive-quantitative. Descriptive method is used to obtain a complete and accurate description of a situation (Kuncoro, 2011; 17). Quantitative research methods are research methods that are based on the philosophy of positivism, used to examine specific populations or samples (Sugiono, 2008). Based on definition above, it can be concluded that descriptivequantitative research is research that aims to describe data or numbers that have been processed in accordance with certain standards. In this study, the examined sample was 70 Indonesian University of Education (UPI) students who represented each faculty. 


\section{RESULTS AND DISCUSSION}

Literacy Level of Indonesian University of Education (UPI) Students about Sharia Cooperatives Based on the results of the study, 70 respondents consisted of 49 women and 21 men. This means that the number of women dominates compared to men. In terms of age, age 19 years occupies the most positions, amounting to 33 people or around $47.1 \%$. The Faculty of FPEB is the faculty with the highest number of respondents with a background in education graduates from high schools majoring in Natural Sciences. Most respondents came from West Java with an income of less than one million rupiah. The following is the:

\section{Table 1.}

The description of the respondent's charactersCharacteristics of Respondents

\begin{tabular}{|c|c|c|c|}
\hline Variable & Description & $\begin{array}{c}\text { Number of } \\
\text { Respondents }\end{array}$ & $\begin{array}{l}\text { Percentages of } \\
\text { Respondents }\end{array}$ \\
\hline \multirow[t]{2}{*}{ Gender } & Men & 21 & 30 \\
\hline & Women & 49 & 70 \\
\hline \multirow[t]{6}{*}{ Age } & 17 years & 1 & 1.4 \\
\hline & 18 years & 12 & 17.1 \\
\hline & 19 years & 33 & 47.1 \\
\hline & 20 years & 16 & 22,9 \\
\hline & 21 years & 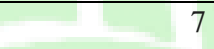 & 10 \\
\hline & years 25 & 1 & 1.4 \\
\hline \multirow[t]{5}{*}{ Faculty } & FPEB & 27 & 38.5 \\
\hline & FPMIPA & 9 & 12.9 \\
\hline & FPIPS & 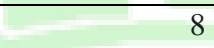 & +2 \\
\hline & FIP & +2 & +2 \\
\hline & Other & 13 & 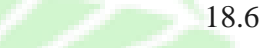 \\
\hline \multirow[t]{3}{*}{ Education } & High School / IPA & 39 & 55.7 \\
\hline & SMA /IPS & 22 & 31.4 \\
\hline & SMK/ Aliyah & 9 & 12.9 \\
\hline \multirow[t]{4}{*}{ Origin of } & West Java & 66 & 94.3 \\
\hline & DKI Jakarta & 2 & 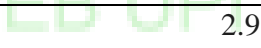 \\
\hline & Central Java & 1 & 1.4 \\
\hline & Outside Java & 1 & 1.4 \\
\hline \multirow[t]{3}{*}{ Revenue } & $<$ Rp. $1,000,000$ & 45 & 64.3 \\
\hline & Rp. $1,000,000-$ Rp. $2,000,000$ & 23 & 32.9 \\
\hline & > Rp. $2,000,000$ & 2 & 2.9 \\
\hline
\end{tabular}

Source: results of data processing 
The results of the study generally showed the level of student literacy at Universitas Pendidikan Indonesia (UPI) about Sharia Cooperatives from each dimension assessed as follows:

\section{The Chart 1}

\section{Knowledge of Sharia Cooperatives}

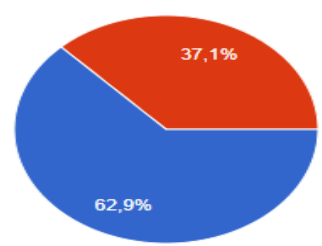

From 70 respondents, with a percentage of $62,9 \%$, ie 44 respondents knew of Islamic cooperatives while $37,1 \%$, namely 26 respondents did not know about Islamic cooperatives. Based on the results of the study showed that most UPI students already knew about Sharia Cooperatives.

\section{The Charts 2 Sources of information about Islamic cooperatives}
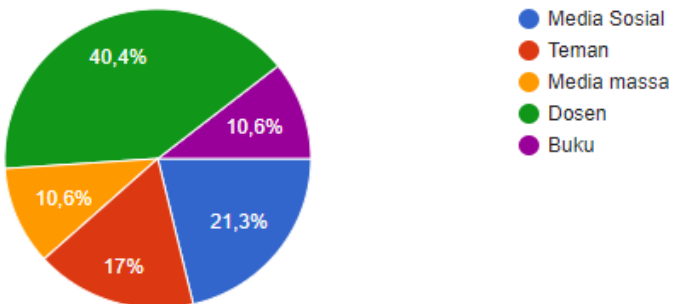

The 70 respondents, $40.4 \%$ of respondents knew of Islamic cooperatives from lecturers, $21.3 \%$ from social media, $17 \%$ of respondents knew from friends, 10.6 respondents knew from books, and $10.6 \%$ of the recipes knew from the mass media.

\section{The Charts 3 Literacy about the Contract}
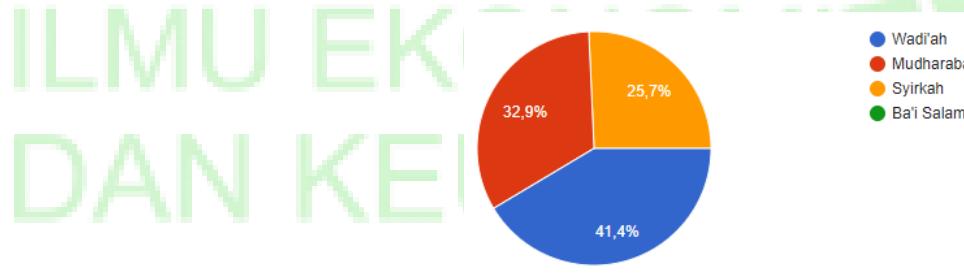

- Mudharaba Syirkah

The 70 student respondents, $41.4 \%$ of respondents or 29 people answered the contract used in the development of Islamic cooperatives using the Wadiah contract in savings products, there were 32.9 respondents or 26 people who answered the mudhrobah contract and $25.7 \%$ of respondents who choose to use the syirkah contract in Islamic cooperatives. Based on this, UPI students do not fully understand the development agreement used in Islamic cooperatives, it can be seen from the data of respondents who understand that cooperatives are syirkah contracts as much as $25.7 \%$.

\section{The Charts 4 Understanding About Usury}

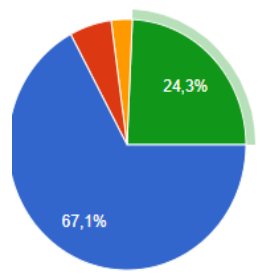

- Penambahan atas harta pokok Penimbunan monopoli barang - Segala transaksi yang tidak

- Segala bentuk spekulasi judi yang mematikan sekto rill dan tidak 
From 70 respondents, $67.1 \%$ answered that usury is an addition to the basic assets, as many as $24.3 \%$ of respondents answered usury is all forms of gambling speculation contained in the real and non-real sectors, as much as $5.7 \%$ or 4 people say usury is a monopoly stockpiling of goods, and 2 people say usury is any transaction that is not transparent. Based on the answers above, it can be concluded that most UPI students already understand what is meant by usury.

\section{The Charts 5 Suitability of Islamic Cooperatives with Islamic Principles}

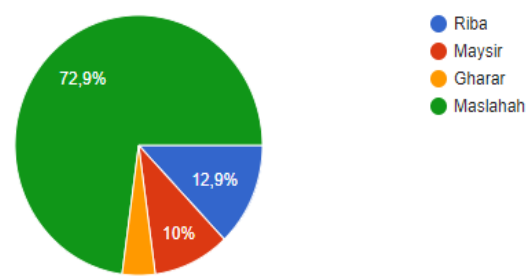

The 70 respondents, things that are not allowed in Islamic cooperatives based on Islamic principles include $79.2 \%$ answering problems, $12.9 \%$ answering usury, $10 \%$ of respondents answering maysir, $3 \%$ answering gharar. Based on the results of the study that most students have understood the suitability of Islamic cooperatives with Islamic principles.

\section{Ulama's View of Cooperatives}

Asnawi $(1987 ; 173)$ argues that in cooperatives there is conformity with Islamic ethical principles, so according to him it is obligatory for Muslims to participate in Islamic cooperatives. As for Abdurahman Isa, the cooperative is syrkah taáwuniyah, which is syrkah musahamah. This means that cooperatives are formed from shares owned by their members. He further revealed that amwal syrkah which consists of a collection of capital, not syrkah asykah which means a collection of people or bodies. However, he argues that cooperatives may be in Islam and dividends received by members may, as long as the cooperative does not contain usury and does not conflict with Islamic principles. (Norvadewi; 2007)

But there are also those who hold the opposite view. This is based on the existence of conditions and principles that are considered contrary to Islamic principles. As stated by Khalid Abdurahman explained in his book entitled al-jami'ah al-Ta'awuniyah concluded that cooperating for Muslims is unlawful, and as a consequence he also forbids property generated from cooperative activities. (Norvadewi; 2007) The

The argument is first, caused by organizational principles that do not meet the requirements established by sharia. Second, namely regarding the terms of profit sharing. Cooperatives recognize the distribution of profits in terms of buying or selling members of the cooperative. This method is considered to deviate from the teachings of Islam because according to the form of syirkah only recognize the distribution of profits on the basis of capital, on the basis of effort or on the basis of both. Third, that is based on his assessment of the main purpose of the formation of cooperatives with the requirements of members of the weak economic groups which he considered only intended to appease them and limit their desires and to play with them with utopian utterances or theories. (Norvadewi; 2007).

Furthermore An-Nabhani (2015) in his book al-Nizam al-Iqtishadl fi al-Islam calls cooperatives the term al-Jam'iyyah al-Ta'awuniyyah. An Nabhani more clearly states that the law for cooperative activities is invisible. This is based on several arguments, namely: First, cooperatives are included in syirkah where cooperatives occur in cooperation to establish business partners. One of the most important requirements in the syirkah agreement is the existence of the body element, then the capital element. The element of the body in question is the partner party personnel and the body element determines the presence or absence of syirkah. In cooperatives only bersyirkah with the participation of capital / assets with the aim of organizing managers who run cooperative activities.

Second, profit sharing in cooperatives based on member services, whether in the form of production, sales, purchases or so on, is not based on assets or working capital. In syar'i if syirkah happens to assets, the distribution of profits must be based on assets, if it happens to work must be 
based on work, and if it occurs in both, the distribution of data must be in accordance with both. Therefore, profit sharing in a cooperative is not legal, because it is not in accordance with the contract. In cooperatives, the distribution of profits is based on sales, purchases, and so on, whereas the cooperative agreement is on assets. Therefore, the contract carried out by the facade because there is one condition that is not fulfilled.

Meanwhile, Masjfuk Zuhdi explained that cooperatives provide a fixed percentage of profits each year to members. This contradicts the principle of Islamic economics which relies that profits must be based on profits and losses. (Zuhdi; 1988).

\section{CONCLUSION}

Cooperatives are business entities consisting of individuals or cooperative legal entities by basing their activities based on cooperative principles and at the same time as a people's economic movement based on the principle of kinship. Whereas Sharia cooperatives are a type of joint business consisting of individuals or legal entities, with a family system which in its implementation is based on sharia principles.

The level of UPI students 'literacy towards sharia cooperatives shows that students do not fully understand the development covenants used in sharia cooperatives which are included in thecovenant syirkah, but in general the students' literacy towards usury and the suitability of Islamic cooperatives with Islamic principles is largely known.

\section{REFERENCE}

Ayadi, R., Llewellyn, D. T., Schmidt, R. H., Arbak, E., \& Pieter De Groen, W. (2010). Investigating diversity in the banking sector in Europe: Key developments, performance and role of cooperative banks.

Shafii, Z., Obaidullah, M., \& Samad, R. R. (2017). Developing a Model for Corporate Governance and Conflict of Interest Deterrence in Shari'ahbased Cooperatives. IRTI Policy Paper, (2017$03)$.

Kartasapoetra, Praktek PengelolaanKoperasi, Jakarta: Rineka Cipta, 2013, h.5 1.

OJK, O. J. K. (2017). In Roadmap Pengembangan Kewangan Syariah Indonesia 2017-2019. Jakarta: Otoritas Perkhidmatan Kewangan.

Nuryana, Y., \& Surjandari, D. A. (2019). The Effect of Good Corporate Governance Mechanism, and Earning Management on Company Financial Performance. Global Journal of Management and Business Research.

Marlina, R., \& Pratama, Y. Y. (2017). KOPERASI SYARIAH SEBAGAI SOLUSI PENERAPAN AKAD SYRIKAH YANG SAH. Amwaluna: Jurnal Ekonomi dan Keuangan Syariah, 1(2), 263-275.

Juliana, J., Qudsi, F. S., Disman, D., \& Marlina, R. (2019). Sharia Compliance: Case Study on Murabahah Product BMT ItQan. KnE Social Sciences, 914-923.

Revrisond, B. (2000). koperasi Indonesia. Edisi pertama, Penerbit BPFE-Yogyakarta.

Zaidi. (2005). Additional Diversity through Space-Time-Frequency Block Coding for Cooperative Communications. submitted to IEEE Transactions on Signal Processing, 19, 1289-1294. 
Kemu, Suparman Zen. Pusat Kebijakan Sektor Keuangan Badan Kebijakan Fiskal, Indonesia. Vol 21, No 2 (2016).

Irwin Jr, C. E. (1993). Adolescence and risk taking: How are they related.

Borim, F. S. A., Francisco, P. M. S. B., \& Neri, A. L. (2017). Sociodemographic and health factors associated with mortality in community-dwelling elderly. Revista de saude publica, 51, 42.

Kuncoro, M. (2011). Metode Kuantitatif: Teori dan Aplikasi untuk Bisnis \& Ekonomi. Yogyakarta: Upp Stim Ykpn.

Sugiyono. (2008). Metode penelitian pendidikan:(pendekatan kuantitatif, kualitatif dan $R \& D$ ). Alfabeta.

Norvadewi, N. (2007). KONSEP DAN OPERASIONALISASI PEGADAIAN SYARIAH. Mazahib, $4(1)$.

An-Nabhani, T. (2015). Konsepsi Politik Hizbut Tahrir, terj. M. Shiddiq Al Jawi, Jakarta: Hizbut Tahrir Indonesia.

Zuhdi, M. (1988). Masail fiqhiyah: kapita selekta hukum Islam. Haji Masagung. 